REVIEW

\title{
Main Erythrocyte Antigens Involved in the Alloimmunization Process
}

\author{
Aline Akemi Segatti $\mathrm{Ido}^{1}$, Mario Cezar de Oliveira ${ }^{1 *}$ \\ ${ }^{1}$ Federal University of Uberlandia, Brazil \\ *Corresponding author: Mario Cezar de Oliveira: mario.oliveira@ufu.br
}

\section{OPEN ACCESS}

Citation: Ido A.A.S., Oliveira M.C. (2020) Main Erythrocyte Antigens Involved in the Alloimmunization

Process. Open Science Journal 5(2)

Received: $13^{\text {th }}$ May 2020

Accepted: $31^{\text {st }}$ May 2020

Published: $24^{\text {th }}$ June 2020

Copyright: (C) 2020 This is an open access article under the terms of the Creative Commons Attribution License, which permits unrestricted use, distribution, and reproduction in any medium, provided the original author and source are credited.

Funding: The author(s) received no specific funding for this work

Competing Interests: The author has declared that no competing interests exists.

\begin{abstract}
:
Erythrocyte alloimmunization occurs when an individual produces antibodies to antigens on the donor's red blood cell, which the immune system identifies as a foreign element to the organism. It represents one of the greatest risks faced by patients undergoing transfusion therapy, reducing the possibility of finding compatible red blood cells in future transfusions. The immune system of the human being has the ability to recognize what is proper to its genome from what is not proper, being able to stimulate an immune reaction against foreign substances. Upon contact with different antigens present in the donor red blood cell, the recipient of the blood may trigger an immune response by generating antibodies against nonself antigens due to sensitization, such as post-pregnancy or primary transfusion, which may trigger lysis of transfused red blood cells. Exposure to large numbers of nonself antigens may lead to the formation of alloantibodies causing intra- or extravascular haemolytic transfusion reaction. Polytransfused patients are more likely to develop alloantibodies, approximately $1 \%$ for each transfused unit. This percentage may be higher in sickle cell patients $(36 \%)$, thalassemia patients (10\%) and people with myelo and lymphoproliferative diseases $(9 \%)$.
\end{abstract}

Keywords: Alloimmunization, Irregular antibody search, Blood transfusion, Blood transfusion reaction. 


\section{Introduction}

The use of blood to return to homeostasis is a technique used by humans for centuries. The first difficulty in transfusion practice occurred in 1492, when Italian Pope Innocent VIII received blood transfusions from three young men in an attempt to save the life of the pontiff who faced severe kidney problems. The practice was unsuccessful, with the pope and the three donors dying shortly after the procedure. Several attempts were unsuccessful, such as the transfusion of blood from other species to man [1].

In 1667, French physician Jean Baptiste Denis transfused animal blood into humans, apparently without causing them any problems. However, on transfusing the patient for the second time, the patient had a Hemolytic Transfusion Reaction (RTH), and died sometime later. At that time, due to the great controversy caused, the Faculty of Medicine of Paris, together with the French Parliament and the Italian Pope Innocent XI prevented the practice of blood transfusion. The first major success of blood transfusion was performed by the English obstetrician and physiologist James Blundell in 1818. He transfused his postpartum hemorrhage patient, noting that the transfusion could only be performed between individuals of the same species [1].

The discovery of the ABO system in 1900 by Austrian physician and scientist Karl Landsteiner was a major achievement for transfusion therapy. He performed various procedures by mixing plasma and red blood cells from different people, noting that in some cases there was formation of cell clumps (agglutination) and in others not. This practice contributed to the determination of $\mathrm{A}, \mathrm{B}$ and $\mathrm{O}$ blood groups. AB blood group was only discovered two years later by Alfredo Castello and Adriano Sturli [2,3].

After 40 years of the discovery of the ABO system, Landsteiner and Alexander Wiener announced another important system for the transfusion procedure: the $\mathrm{Rh}$ system. This system allowed the identification of blood according to the presence or absence of antigen $\mathrm{D}$, being classified as Rh positive (presence of antigen D) and Rh negative (absence of antigen D). After this period, immunohematology was able to complete the understanding of the incompatibility between the different bloods that caused adverse events resulting from transfusions $[4,5]$.

\section{Red blood cell surface}

Red blood cells are non-nucleus cells that carry oxygen (O2) to all body tissues and remove carbon dioxide (CO2) from the tissues to be eliminated by the lungs. It contains within it the hemoglobin protein that carries these gases. Erythrocytes have an average life of 120 days. As these cells become old and defective, the spleen sequester them and remove them from the circulation and the bone marrow releases new cells into the circulation [6].

Red blood cells are formed by a semipermeable lipid bilayer supported by a protein cytoskeleton. Its membrane is composed of carbohydrates linked to proteins (glycoproteins) or lipids (glycolipids), asymmetrically organized, which are present in the cellular glycocalyx. The biochemical composition of the red blood cell surface is approximately $8 \%$ carbohydrate, $40 \%$ lipid and most of it $52 \%$ protein $[7,8]$. In addition, the red cell membrane is characterized by the presence or absence of blood group antigens which are macromolecular 
arrangements composed of carbohydrates or proteins. The diversity of genes involved in protein production leads to the formation of various erythrocyte antigens which is the major factor responsible for the formation of irregular antibodies in the plasma of alloimmunized individuals $[2,9]$.

Since the discovery of the ABO System, studies have detected that there are other antigens present on the surface of red blood cells that could cause reactions to the transfused patient. 363 erythrocyte antigens are already known, of which 322 are grouped in 38 different systems and the rest are in high or low frequency collections or series [10].

\section{Risks of blood transfusion}

When properly evaluated and prescribed, transfusion therapy can offer benefits, improving quality and saving the lives of patients with severe bleeding [4]. Currently, transfusion medicine is one of the five most performed practices in the world, with $10 \%$ of hospitalized patients receiving blood transfusion prescriptions [11]. Chronic transfusions expose the individual to various risks from microorganisms, iron overload and alloimmunization [12].

According to a report published by the Risk Monitoring Management of the National Health Surveillance Agency (ANVISA), 10.547 transfusion reactions were reported in Brazil in the period 2007-2015. The estimate used by ANVISA was three reactions per 1000 transfusions, however, in its new report they reported that this number may be around five notifications per 1000 transfusions performed [13].

The transfusion procedure is capable of causing variable adverse reactions, which may be the reason for the increased morbidity and / or mortality of this practice. These reactions may be of immediate or late immunological origin, which may lead to mild to acute responses to the patient that may be prevented. Severe complications, which pose a fatal risk to the patient, have a lower incidence, while mild adverse events are common in transfusion practice, especially in patients on chronic transfusion regimens [8, 14, 15].

Among the most common causes of transfusion reactions are hemolytic reaction and TRALI (acute transfusion-associated lung injury). The hemolytic reaction occurs by the previous formation of antibodies that recognize the corresponding erythrocyte antigens, bind to it and cause intravascular or extravascular hemolysis. In TRALI there is an acute reaction with symptoms of respiratory distress and severe hypoxemia at the time of transfusion or up to 6 hours after transfusion [8].

\section{Erythrocyte alloimmunization}

The production of specific antibodies in erythrocyte alloimmunization occurs soon after the entry of blood containing nonself antigens present in the donor red blood cell. The number of transfusions received, antigenic differences, receptor immune response, and antigen immunogenicity are some factors that induce a higher rate of alloimmunization $[2,8]$.

When the individual is exposed to red blood cells with different erythrocyte antigens through blood transfusion or pregnancy, the immune system recognizes transfused red blood cells as a foreign body and a specific response occurs to 
eliminate it. When this foreign body is encountered by the immune system, B cells recognize, activate and secrete relevant antibodies. However, the cellular process involving humoral alloimmunization is quite complicated, involving several cell types (macrophages, dendritic cells and $\mathrm{T}$ lymphocytes) at different stages of maturation and activation [16].

Following this recognition, B cells produce antibodies of the IgM class as a primary response. Detection of these antibodies may be revealed by immunohematological tests within weeks to months, depending on the immunological response of each patient. When exposed to the same antigen a second time, the patient will manifest a secondary response with the production of IgG class immunoglobulins, which response is much faster, ranging from 48-72 hours after the second transfusion, stimulated by memory cells (B lymphocytes) developed after the first transfusion [17].

Antibodies can be classified according to antigenic stimulus. Regular antibodies are those that are naturally occurring, found in individuals who have not at any time been exposed to antigens by transfusion, pregnancy or vaccine. Most of these antibodies belong to the IgM class, react better at room temperatures $\left(22-24^{0} \mathrm{C}\right)$ or below, do not cross the placental barrier, may activate the complement system, and when activated at $37{ }^{\circ} \mathrm{C}$ may cause hemolysis. Examples of such antibodies are those present in the ABO, Hh, li, Lewis, MN and $\mathrm{P}$ system [18].

Unexpectedly occurring antibodies are classified as irregular. They are produced as a reaction of the immune system against a nonself antigen, due to previous sensitization caused by the contact of erythrocyte antigens in cases of pregnancy or blood transfusion [3]. Most are IgG class immunoglobulins, react better at $37{ }^{0} \mathrm{C}$, are able to cross the placental barrier and can cause severe hemolytic reactions [18].

When a patient is alloimmunized, matching red blood cell pockets will be more difficult, requiring the location of a pouch that does not contain the antigen for which the patient developed the antibody on the surface of the red cell. In addition, the presence of alloantibodies significantly increases the risk of hemolytic transfusion reaction $[8,19]$.

\section{Main erythrocyte antigens}

In recent years, the main objective in the practice of transfusion therapy has been to reduce the risk of alloimmunization in patients, especially those who need frequent transfusions. There are currently cataloged in the International Society of Blood Transfusion (ISBT) 363 erythrocyte antigens, 322 of which are classified into 38 different systems and 38 antigens contained in low and high frequency collections or series. Among these 36 different systems, we highlight the ABO, Rh, Kell, Duffy, Kidd, Diego, Lewis and MNS systems [10, 18, 20].

\section{ABO system}

$\mathrm{ABH}$ antigens are formed by complex carbohydrate molecules where there is the interaction of $\mathrm{A}, \mathrm{B}$ and $\mathrm{H}$ genes. The $\mathrm{H}$ gene is responsible for the formation of $\mathrm{H}$ antigen which is a precursor structure of the antigens of the $\mathrm{ABO}$ system in red blood cells. These genes encode the production of specific glycosyltransferases, which are catalyst enzymes that have the function of uniting different 
carbohydrate structures, which add immunodominant sugars for the expression of an inherited blood type. About $99.99 \%$ of individuals inherit the $\mathrm{H}$ gene from their parents (HH or Hh genotype). When a person has the hh genotype, he does not express the $\mathrm{H}$ gene, and this blood type is classified as Bombay or false $\mathrm{O}[8$, $21]$.

Blood group $\mathrm{O}$ is a recessive phenotype, it has the precursor $\mathrm{H}$ gene that expresses only $\alpha$-2-L-fucosyltransferase that will add in its terminal position the sugar fucose in its structure. Since group $O$ does not have a functional enzyme, this individual will only express on its membrane the $\mathrm{H}$ antigen [2].

Blood type A formation is determined by the expression of $\mathrm{A}$ gene which will encode $\alpha$-3-N-acetylgalactosaminyltransferase glycosyltransferase production which will have in the terminal region the immunodominant sugar N-acetyl-Dgalactosamine linked to the $\mathrm{H}$ antigen [8].

Blood type $\mathrm{B}$ formation is determined by the expression of $\mathrm{B}$ gene which will encode $\alpha$-3-D-galactosyltransferase glycosyltransferase production with the consequent binding to the immunodominant sugar D-galactose, which sugar is responsible for the specificity of blood B group [8].

In the ABO system we find antibodies that are called natural or regular. They are formed from passive stimuli, such as exposure to environmental antigens, food, or mainly gut bacteria, which contain sugars in their cell membranes that are similar to the immunodominant sugars exposed in the red blood cell membrane [2].

\section{Rh system}

After the ABO system, the Rh system is considered the most important in terms of transfusion. They present immunogenic antigens, that is, they have a greater capacity to stimulate the production of antibodies. Unlike the ABO system that has natural antibodies (anti-A and anti-B), the Rh system does not produce it and on exposure to non-self antigens will produce irregular antibodies. The lipoproteins of the Rh system are unique to the red blood cells and cross the erythrocyte membrane twelve times, forming a structure called loops, which have a structural and gas transport function $[2,9]$. Within the $\mathrm{Rh}$ system, 55 different antigens are cataloged, and only D antigen screening in patients receiving blood transfusion is mandatory. However, this system has 54 different antigens that can cause alloimmunization and consequently hemolytic reactions [10, 22].

The Rh system is controlled by the RHD and RHCE genes. The RHD gene encodes the RhD protein, and Rh positive ( $\mathrm{D}$ antigen) individuals have this gene and Rh negative (D antigen) individuals do not or cannot express this gene. The second gene, RHCE, encodes the expression of RhCE, RhCe, RhcE and Rhce proteins [8].

Rh system antigens may form antibodies of the $G$ immunoglobulin class, which may cross the placental barrier and generate extravascular hemolytic reactions. Rh genes are considered codominants, with each inherited gene expressing the corresponding antigen. After D antigen, c antigen is the most immunogenic, followed by E antigen, $\mathrm{C}$ antigen and then e antigen [8, 9, 23].

More in the $\mathrm{Rh}$ system, $\mathrm{C}^{\mathrm{W}}$ antigen is considered a low frequency antigen, found in only $2 \%$ of the white population and is very rare in the black population. For this reason $\mathrm{C}^{\mathrm{W}}$ antigen negative blood is readily available. However, when the patient produce anti- $\mathrm{C}^{\mathrm{W}}$ antibodies resulting from red blood cell transfusion with the positive $\mathrm{CW}^{\mathrm{W}}$ antigen, the patient may have clinically significant transfusion reactions [8]. 


\section{Kell system}

Another important system in transfusion practice is the Kell system, which was the first blood group system to be discovered after the introduction of the Coombs test. In this system 36 high and low prevalence antigens are described [10]. It is an antigen that has enzymatic function and is related to an endothelin converting enzyme, which is a potent vasoconstrictor. Kell system antibodies are considered strongly immunogenic, have a high incidence and are capable of causing severe transfusion reactions $[25,26,27]$.

\section{Duffy system}

The Duffy system was first reported in 1950. It has five different types of antigens $\left(\mathrm{Fy}^{\mathrm{a}}, \mathrm{Fy}^{\mathrm{b}}\right.$, Fy3, Fy5 and Fy6). Antibodies formed against this system's antigens belong to the IgG class, may activate the complement system and are clinically significant $[2,10]$. Duffy glycoprotein is a receptor for proinflammatory chemokines and also has the function of Plasmodium vivax merozoite receptor (etiological agent of malaria) [24]. The incidence of this phenotype is not common among blacks, especially from Africa, which would explain blacks' resistance to malaria [8].

\section{Kidd system}

The Kidd system, described between 1951 and 1953. There are cataloged in this system three different antigens $\left(\mathrm{Jk}^{\mathrm{a}}, \mathrm{Jk}^{\mathrm{b}}\right.$ and $\left.\mathrm{Jk} 3\right)$ and its structure is an integral protein that has urea transport function. It has moderate immunogenicity, but is involved in severe hemolytic reactions [2]. Antigens of this system are of high prevalence, found in most of the population [8].

\section{Diego system}

The Diego system was described in 1955 . There are 22 different cataloged antigens in this system that have the biological function of anion transport (HCO3- and $\mathrm{Cl}-$ ) and are markers of old red blood cells that must be removed from the bloodstream. This system can induce the formation of IgM and IgG class antibodies. They are low prevalence antibodies, usually associated with Newborn Hemolytic Disease [2, 10].

\section{Lewis system}

The Lewis system was discovered in 1948 and there are six antigens $\left(\mathrm{Le}^{\mathrm{a}}, \mathrm{Le}^{\mathrm{b}}\right.$, $\mathrm{Le}^{\mathrm{ab}}, \mathrm{Le}^{\mathrm{bH}}, \mathrm{ALe}^{\mathrm{b}}$ and $\mathrm{BLe}^{\mathrm{b}}$ ) cataloged. Generally the antibodies formed are naturally occurring and belong to the IgM class. They rarely cause hemolytic reactions; however, reactivity at $37{ }^{\circ} \mathrm{C}$ may activate the complement system and trigger severe hemolytic conditions [2].

\section{MNS system}

Landsteiner and Levine discovered the MNS system shortly after the discovery of the ABO system. Currently 49 antigens have been described in this system, most of them naturally occurring and belonging to the IgM class. Anti-M and 
anti- $\mathrm{N}$ antibodies are not clinically relevant, but anti-S and anti-s antibodies can cause severe reactions and are reactive at $37{ }^{\circ} \mathrm{C}[10,18]$.

\section{Complications due to alloimmunization}

The most serious complication related to transfusion is the occurrence of Hemolytic Immune Transfusion Reaction (RTIH). This RTIH occurs when transfused blood is hemolysed, caused by the pre-existence of antibodies in the blood plasma, which may be caused by regular ABO system antibodies or by irregular antibodies due to alloimmunization due to previous exposure to other blood antigens [7].

The severity of hemolytic transfusion reaction signs and symptoms is directly related to the speed and amount of incompatible blood transfused. A small amount of transfused blood $(10 \mathrm{ml})$ can cause symptoms such as: feeling of impending death, pain at the infusion site, back, flanks and abdomen. In addition, the patient may show signs of hypotension, hemoglobinuria, hemoglobinemia, and shock [8].

Binding of immunoglobulin to erythrocyte antigen may activate the complement system by the classical pathway and cause hemolysis. ABO incompatibility corresponds to the most severe hemolytic reaction, as anti-A and anti-B antibodies are present in large quantities in blood plasma. Intravascular hemolysis occurs by activation of the complement system and resulting in cell lysis [7, 28].

The antigen-antibody complex may cause extravascular hemolysis. This type of reaction occurs by sensitization of red blood cells by IgG class antibodies or by the activation of the complement system. Red blood cells bound to antibodies or expressing complement system proteins are phagocyted by monocytes and taken to the liver or spleen, where they will be destroyed in a matter of minutes, such as antibodies directed to the Kidd and Duffy system. This recognition can also occur when the monocyte recognizes and binds to the antibody without complement system activation [8, 28].

Another type of reaction resulting from alloimmunization is Late Haemolytic Immune Transfusion Reaction (RTIHT) which causes extravascular hemolysis and usually occurs 24 hours to two weeks after blood transfusion and is directed primarily against the Rh, Kidd, Duffy and Kell antigens [2, 7].

\section{Strategies for the prevention of alloimmunization}

Erythrocyte phenotyping is based on identifying which antigens are exposed on the surface of red blood cells. Currently, Brazilian legislation recommends testing prior to the act of blood transfusion, which includes ABO phenotyping, RhD phenotyping, Irregular Antibody Research and Compatibility test, observing whether or not agglutination reaction [22, 29].

However, patients with chronic transfusions are more likely to develop alloantibodies because they are exposed to a wide variety of different antigens with each transfusion. Phenotyping patients and blood bags against other more prevalent antigens is a way to significantly reduce alloimmunization [30]. 
Several studies point out that most antibodies produced by alloimmunization belong to the Rh and Kell systems, the most prominent being E, e, C, c, Cw and Kell [27, 30]. Therefore, research on these antigens can be very helpful in reducing the risk of alloimmunization [26]. According to the need for Hemotherapy services, the Brazilian Ministry of Health recommends phenotyping of Rh (D, C, c, E, e) and Kell (K1) erythrocyte antigens in blood samples from blood donors. In addition, for patients who may undergo chronic transfusion regimens, phenotyping for the erythrocyte antigens of the $\mathrm{Rh}$ (E, e, C, c), Kell $(\mathrm{K})$, Duffy $\left(\mathrm{Fy}^{\mathrm{a}}, \mathrm{Fy}^{\mathrm{b}}\right)$, Kidd $\left(\mathrm{Jk}^{\mathrm{a}}, \mathrm{Jk}^{\mathrm{b}}\right)$ systems and $\mathrm{MNS}(\mathrm{S}, \mathrm{s})$ can be a great help for the prevention of alloimmunization [22].

\section{Conclusions}

The performance of blood transfusion was a landmark of great relevance for medicine. Blood is an important therapeutic tool that continues to contribute more and more to the survival and quality of life of people who need frequent transfusions, either by surgical procedures requiring replacement of lost blood, or by degenerative and chronic diseases.

However, it is necessary that blood transfusion be seen as a complex procedure, as well as a transplant, which may trigger greater risks than benefits to the patient. Knowing the diversity of antigens that may be present in the donor's red blood cell and understanding how the recipient patient's immune system may respond to this procedure is crucial to understanding the great responsibility of subjecting a patient to blood transfusion.

Laboratory tests, identifying possible problems that may occur at the time of transfusion, are of great importance for the success of the procedure. However, for patients with chronic transfusion regimens, it would be important to adopt conducts for identifying other blood systems besides the $\mathrm{ABO} / \mathrm{RhD}$ systems, with extended phenotyping of the MNS (S, s), Duffy $\left(\mathrm{Fy}^{\mathrm{a}}, \mathrm{Fy}^{\mathrm{b}}\right)$, Kidd $\left(\mathrm{Jk}^{\mathrm{a}}, \mathrm{Jk}^{\mathrm{b}}\right)$ systems and mainly Kell (K) and Rh (E, e, C, c) system antigens.

The correct assessment and prescription of blood transfusion by the attending physician in conjunction with preventive and safe measures adopted by transfusion agencies, matching the $\mathrm{ABO}, \mathrm{Rh}(\mathrm{D}, \mathrm{E}, \mathrm{e}, \mathrm{C}, \mathrm{c})$ and Kell systems, may offer a lower chance of erythrocyte alloimmunization may occur in polytransfused patients.

\section{References:}

1. Verrastro t, Lorenzi tf, Neto S. W. Hematologia e hemoterapia: fundamentos de morfologia, fisiologia, patologia e clínica. 1. Ed. São Paulo: Atheneu, 2010. 303 p.

2. Girello al, Kühn Tibb. Fundamentos da imuno-hematologia eritrocitária. 4. Ed. São Paulo: Senac São Paulo, 2016. 327 p.

3. Baptista Mwg, Nardin JM, Stinghen ST. Aloimunização eritrocitária em pacientes de um hospital infantil atendido pelo Instituto Paranaense de Hemoterapia e Hematologia, de 2007 a 2010. Cadernos da Escola de Saúde, Curitiba, v. 2, n. 6, p. 131-142, 2017.

4. Brasil. Ministério da Saúde. Secretaria de Gestão do Trabalho e da Educação na Saúde. Técnico em hemoterapia: livro texto. Brasília, DF, 2013.

5. Marcondes SS. Aplicação do índice de pacientes transfundidos e do índice de utilização de concentrado de hemácias no serviço de Hemoterapia do Hospital Universitário Cassiano Antônio de Moraes, como ferramenta para melhoria das práticas hemoterápicas transfusionais [dissertação]. Centro de Ciências da Saúde, Universidade Federal do Espírito Santo, Vitória, 2017, 93 p. 
6. Tortora GJ, Derrickson B. Princípios de anatomia e fisiologia. 12. Ed. Rio de Janeiro: Guanabara, 2010. 1228 p.

7. Sweeney JD, Rizk Y. Manual prático de hemoterapia. 1. Ed. Rio de Janeiro: Revinter, 2005. 173 p.

8. Harmening DM. Técnicas modernas em banco de sangue e transfusão. 6. Ed. Rio de Janeiro: Revinter, 2015. 684 p.

9.Sutter B, Paulo MP, Bordini CV, DA Costa DC, Geraldo A. Estabilidade de antígenos eritrocitários humanos para controle interno da qualidade imunohematológico. Revista Brasileira de Análises Clínicas, v. 49, n. 3, p. 275-282, 2017.

10.International society of blood transfusion - ISBT - Holanda. Disponível em:http://www.isbtweb.org/fileadmin/user_upload/Working_parties/WP_on_Red_Cell_Im munogenetics_and/Table_of_blood_group_antigens_within_systems_v8.1_181111.pdf. Acesso em: 22 outubro 2019 .

11. Barreto GS. Transfusão de sangue: do doador ao paciente/caso Cuiabá - MT. Revista Científica Multidisciplinar Núcleo do Conhecimento, v. 8, n. 1, p. 276-314, 2016.

12. Helman R, Cançado RD, Olivatto C. Incidência de aloimunização eritrocitária em pacientes com doença falciforme: experiência de um centro de São Paulo. Einstein, v. 9, n. 2, p. 160-164, 2011.

13. Pithan CF. Avaliação do impacto da utilização de ferramenta eletrônica na hemovigilância e do número de transfusões prévias como fator de risco de reações transfusionais imediatas em hospital terciário do Sul do Brasil [tese]. Faculdade de Medicina, Universidade Federal do Rio Grande do Sul, Porto Alegre, 2018, 36 p.

14. Belem, L. F. Nogueira RG, Leite TR, Costa LC, Alves lfp, Caneiro IS . Descrição de reações transfusionais imediatas na Fundação Assistencial da Paraíba, Brasil. Revista Baiana de Saúde Pública, v. 34, n. 4, p. 810-817, 2010.

15. Freire mrlc, Cunha MC, Andrade S. P. Importância dos testes imuno-hematológicos em receptores de sangue e a ocorrência das reações transfusionais. Eletronic Journal of Pharmacy, v. 12, p. 5659, 2015.

16. Zimring JC, Hudson ke. Cellular immune responses in red blood cell alloimmunization. Hematology. American Society of Hematology, v. 2016, n. 1, p. 452-456, 2016.

17. Costa RN. Avaliação da implementação da pesquisa de anticorpos irregulares com hemácias tratadas com enzima nos exames pré-transfusionais de pacientes com neoplasia maligna de mama do Instituto Nacional do Câncer [Dissertação]. Faculdade de Medicina de Ribeirão Preto, Universidade de São Paulo, Ribeirão Preto, 2017, 80 p.

18. Rodrigues AT. Aloimunização dos doadores de sangue como fonte de anti-soros e hemácias raras [Dissertação]. Universidade Estadual Paulista Júlio de Mesquita Filho, Botucatu, 2016, 67 p.

19. Nery CVS. A elaboração de um protocolo de reserva de concentrado de hemácias para cirurgias eletivas realizadas em um hospital público do Distrito Federal como ferramenta para otimização do uso racional do sangue [Dissertação]. Faculdade de Medicina de Ribeirão Preto, Universidade de São Paulo, Ribeirão Preto, 2018, 65 p.

20. Storry JR, Clausen FB, Castilho L, Chen Q, Daniels G, Denomme G, et al. International Society of Blood Transfusion working party on red cell immunogenetics and blood group terminology: report of the Dubai, Copenhagen and Toronto meetings. Vox Sanguinis, v 114, n. 1, p. 95-102, 2019.

21. SA LA. Determinação do papel estrutural que proteínas auxiliares exercem para a ativação das glicosiltransferases na biossíntese de antibióticos macrolídeos [Dissertação]. Instituto de ciências Biomédicas, Universidade de São Paulo, São Paulo, 2017, 25 p.

22. Brasil. Ministério da Saúde. Gabinete do Ministro. Portaria $\mathrm{n}^{\mathrm{O}}$ 158, de 04 de fevereiro de 2016. Redefine o regulamento técnico de procedimentos hemoterápicos. Diário Oficial da União, Brasília, DF, 05 fev. 2016, 37p.

23. Ferreira bm, junior MRP. Determinação da frequência de anticorpos irregulares pós-transfusionais. Universitas: Ciências da Saúde, Brasília, v. 13, n. 2, p. 79-86, 2015.

24. Bonifacio sl, novaretti MCZ. Funções biológicas dos antígenos eritrocitários. Revista Brasileira de Hematologia e Hemoterapia, v. 31, n. 2, p. 104-111, 2009.

25. Alves VM, Martins PRJ, Soares S, Araujo G, Schmidt lc, costa ssm, et al. Pesquisa de aloimunização após transfusão de concentrados de hemácias em um estudo prospectivo. Revista Brasileira de Hematologia e Hemoterapia, v. 34, n. 3, p. 206-211, 2012.

26. Oliveira RC, Braga JRM. Frequência de anticorpos irregulares em serviço de transfusão de sangue em Salvador-BA, no período de 2009 a 2013. Revista Eletrônica Atualiza Saúde, Salvador, v. 2, n. 2, p. $51-57,2015$

27. Martins JTN, Oliveira KR, Honda KR. Frequência de anticorpos irregulares em pacientes transfundidos no Hemocentro Regional de Araguaina-TO (HEMARA-TO), 2009 a 2015. Journal of Oral Investigations, v. 4, n. 1, p. 41-48, 2017.

28. Mcpherson RA, Pincus MR. Diagnósticos clínicos e tratamento por métodos laboratoriais de Henry. 21. Ed. Barueri: Manole, 2012. 1638 p.

29. Galdino kcg, Petroni TF. Importância dos exames imuno-hematológicos na transfusão sanguínea. Revista Saúde unitoledo, Araçatuba, v. 2, n. 1, p. 26-35, 2018. 
30. Melo wes, fraga afc, torres mcmr, pires esf, esteves fam. Aloimunização eritrocitária em pacientes com anemia falciforme atendidos no Hemocentro de Caruaru, Pernambuco, Brasil. Acta Biomedicina Brasiliensia, v. 9, n. 1, p. 122-129, 2018. 